慶應義塾大学学術情報リポジトリ

Keio Associated Repository of Academic resouces

\begin{tabular}{|c|c|}
\hline Title & Different spinal effects of opioid agonists on spinal and spino-bulbo-spinal reflexes in rats \\
\hline \multicolumn{2}{|l|}{ Sub Title } \\
\hline Author & $\begin{array}{l}\text { 鈴木, 岳之(Suzuki, Takeshi) } \\
\text { 永野, 伸郎(Nagano, Nobuo) } \\
\text { 小野, 秀樹(Ono, Hideki) } \\
\text { 福田，英臣(Fukuda, Hideomi) }\end{array}$ \\
\hline Publisher & 共立薬科大学 \\
\hline Publication year & 1990 \\
\hline Jtitle & $\begin{array}{l}\text { 共立薬科大学研究年報 (The annual report of the Kyoritsu College of } \\
\text { Pharmacy). No.35 (1990. ) ,p.66- } 66\end{array}$ \\
\hline \multicolumn{2}{|l|}{ JaLC DOI } \\
\hline \multicolumn{2}{|l|}{ Abstract } \\
\hline Notes & 抄録 \\
\hline Genre & Technical Report \\
\hline URL & $\begin{array}{l}\text { https://koara.lib.keio.ac.jp/xoonips/modules/xoonips/detail.php?koara_id=AN00062898-0000003 } \\
\text { 5-0066 }\end{array}$ \\
\hline
\end{tabular}

慶應義塾大学学術情報リポジトリ(KOARA)に掲載されているコンテンツの著作権は、それぞれの著作者、学会または出版社/発行者に帰属し、その権利は著作権法によって 保護されています。引用にあたっては、著作権法を遵守してご利用ください。

The copyrights of content available on the KeiO Associated Repository of Academic resources (KOARA) belong to the respective authors, academic societies, or publishers/issuers, and these rights are protected by the Japanese Copyright Act. When quoting the content, please follow the Japanese copyright act. 


\title{
Different Spinal Effects of Opioid Agonists on Spinal and Spino-Bulbo-Spinal Reflexes in Rats*
}

\author{
Takeshi Suzuki, Nobuo Nagano**, Hideki Ono** and Hideomi FukUdA** \\ 鈴木岳之，永野伸郎**，小野秀樹**，福田英臣**
}

The effects of morphine-HCl (MOR), methionine-enkephalin (ME) and dynorphin $_{1-13}$ (DYN) on spinal and spino-bulbo-spinal (SBS) reflexes were studied. Although spinal intrathecal administration of MOR $(15 \mu \mathrm{g})$ did not produce any apparent effect on these reflexes, systemically administered MOR ( $3 \mathrm{mg} / \mathrm{kg}$ i.v.) reduced the electrical toe stimulation-induced SBS reflex. Furthermore, MOR (3 mg/kg i.v.) increased the polysynaptic reflex induced by electrical stimulation of low-threshold dorsal root afferents in intact (non-spinal) rats, but not in spinal rats. Intrathecally administred DYN $(0.5$ and $5 \mu \mathrm{g})$ reduced both the electrical toe stimulation-induced spinal and SBS reflexes, while ME $(15 \mu \mathrm{g})$ only reduced the SBS reflex. These results indicate the physiological multiplicity of spinal opioid receptors. MOR may affect supraspinal nuclei but not the spinal pathway which possesses MOR-sensitive opioid receptors, whereas ME and DYN affect spinal opioid peptide receptors and modulate the reflex activities in which they participate.

* 本報告は J Neural Transm [GenSect]（1990）79:1一9に発表.

** 東京大学薬学部毒性薬理 